The longue durée of community engagement - new applications of critical theory in planning research

Dr Peter Matthews

Institute of Building and Urban Design,

School of the Built Environment,

Heriot-Watt University

P.matthews@hw.ac.uk 


\section{The longue durée of community engagement - new applications of critical theory in planning research}

\section{Abstract}

Habermas' critical theory, and particularly his theory of communicative action, has been applied in the theory and practice of communicative planning. The concept of creating a public sphere in planning processes has been used as an "ought" that planners should seek to achieve to create a communicative rationality. Accepting some of the critique of communicative planning from an agonist and Foucauldian perspective, this paper presents a new application of Habermas'

critical theory. Evidence is presented from community activists in two neighbourhoods of their ongoing reflection on the changes to their built environment over 20 years of regeneration. In this context, Habermas' theoretical work does explain the long-term discourse as the community moved towards a shared consensus on their neighbourhood. This is used to suggest that instead of looking for consensus in the tense conflicting of moments of initial engagement planners we should focus on the longue durée, and the Lifeworld of lived experience, where shared subjectivities over the built environment can develop.

\section{Introduction}


Habermas' theory of communicative action has been influential in spatial planning in critiquing rational planning (Fischer, 2003; Forester, 1993), informing the alternative in communicative planning (Forester, 1993; Healey, 1997; Innes \& Booher, 2003), and being applied in pragmatic planning theory (Flyvbjerg, 1998b; 2001; Healey, 2009). By the turn of the millennium it was suggested that communicative planning was the new paradigm of planning theory and practice (Huxley \& Yiftachel, 2000).

This paper uses empirical evidence that reflects on the longer term impacts of development - a 20 year story - to reengage with Habermas' theory of communicative action in planning theory. Whereas in planning theory communicative action is often presented as an "ought" - as the public sphere as something planners should aspire to but can probably never achieve (Flyvbjerg, 1998a; Huxley, 2000) - here is it considered as an "is": an explanation of how people behave communicatively and come to agreement, including with their built environment. Two novel insights for planning theory are offered that have so far been absent in much of the literature. Firstly the paper presents an historical perspective on Habermasian discourse. This evidence from community activists' experience of living with the physical outputs of regeneration - the built environment - is used to suggest that rather than focus on the difficult moment of communicative 
planning between the planner and community, what is equally important in understanding planning and development, and can be explained by communicative action, is the long-term discourse between a community and its built environment long after the planners and other policy-makers have left. Secondly, the validity of this interpretation is shown through further evidence of community activists acting as 'little Habermasians' (Barnett, Clarke et al., 2008) constantly producing an active discourse of what deprivation and regeneration meant to their communities.

The paper is therefore offering a reappraisal of Habermas' possible contribution to planning and new insights into communicative planning theory. Communicative planning has been critiqued from both a theoretical and empirical perspective. The gap between the rhetoric of communicative planning and the reality of difficult community engagement has brought agonist perspectives to the fore, explaining why the discourse between planners and communities is often political and tense rather than rational, or at worse somewhat tokenistic (Bond, 2011; Brand \& Gaffikin, 2007). The insights of agonism have also questioned whether the level of reflexive and empathetic understanding required of communicative planning can ever be achieved (Huxley, 2000). Theoretically, work from a Foucualdian and agonist perspectives have questioned the empowering possibilities of communicative 
planning. Foucauldian analysis has used the methodology of genealogy to uncover the power/knowledge at work within participatory processes (Cruikshank, 1999; Fischler, 2000; McKee, 2009).

Looking over the longue durée in the built environment the paper suggests it is wrong to presume a public sphere can emerge in the rapidity of a planning policy cycle. The persistence of the built environment means a public sphere should not be expected to be solely created by planners before development, but continues through time. Residents will have time to debate and discuss how the new built form responds to their lived experience, and proposals that were once controversial and produced anything but consensus, can become a welcomed change to a neighbourhood, or become part of an ongoing discourse that needs to be recognised in planning processes. The article concludes with some thoughts as to what this may mean for communicative planning and planning theory and practice.

\section{Communicative planning - communication, discourse and} power

The reflexivity of late-modernity (Bernstein, 1983; May \& Perry, 2011) has led to a sustained intellectual project to question claims of expertise or superior knowledge within a differentiated society and polity, including within spatial 
planning theory and practice (Fischer, 2003; Fischer \& Forester, 1993; Wagenaar, 2007). In planning theory, the theoretical perspectives of Habermasian critical theory, agonist theory drawing on the work ofLacan, Mouffe and Zizek, and Foucauldian theory have offered new ways of understanding and doing planning. Some of the debate between these perspectives is rehearsed here - focusing on communication, discourse and power - to frame the empirical data and the theoretical contribution of the paper.

\section{Communication}

Habermas' intellectual project has been to try and salvage the enlightenment from the paradox of rationality (Ashenden \& Owen, 1999; Bernstein, 1985; Finlayson, 2005; Outhwaite, 1996; White, 1995). Further, his programme of critical theory has been offered as a counter to a post-structuralism he sees as playing into the hands of neo-conservatives and their particular brand of rational liberalism (Habermas, 1985). As such it appealed to planning theorists who wish to pursue positive planning in the face of post-modern critiques of modernity (Healey, 2003; Fischer, 2003). It also allowed planning to be re-formed and understood anew as a collaborative, communicative practice in a differentiated world of governance and a networked polity (Healey, Cameron et al., 1995; Rhodes, 1997). 
At the heart of Habermas' critical theory is the argument that that the rationality of the enlightenment, exemplified by the reflexivity in Kant's question of was ist Aufklarung?

(Bernstein, 1985; Foucault, 2003), is a rationality defined by communicative action. In a free public sphere (Habermas, 1989) the Lifeworld, that arena of social life 'geared towards the symbolic production and reproduction of its structural components: culture, society, and personality', can flourish (Cook, 2005: 56-57). Homo democratus can be free to act communicatively, seeking 'agreement [Einverständnis] that terminates in the intersubjective mutuality of reciprocal understanding, shared knowledge, mutual trust, and accord with one another' (Habermas, 1996b: 119). To reach this consensus speakers make a claim for validity based on three standards. The truth claim is judged on: firstly its truth; secondly the speaker's truthfulness (whether they can be trusted); and lastly its rightness (whether it fits into expected norms) (Finlayson, 2005; Habermas, 1996b: 125-126). Through discourse truth claims are presented publicly and the parties to the debate attempt to become reflexively aware of the other's viewpoint to reach agreement (Habermas, 1985; Habermas, 1996b; McCarthy, 1985). Although argued to be a universal pragmatic epistemology, the relativity of truth claims, and especially the rightness of any judgement, means '[t]he typical states are in 
the gray areas in between' (Bernstein, 1983: 120; Habermas, 1996b).

Communicative action has been employed in planning theory because of its emancipatory underpinnings. In Habermas' conception, the Lifeworld offers freedom. The development of modern industrial capitalism means that the Lifeworld been corrupted by the System (Habermas, 1989). Crudely put, this is money and power; but can also be understood as the purposive, strategic rationality - the zweckrationalitat - identified as a threat by Weber (Bernstein, 1985; Cook, 2005; Habermas, 1996a; McCarthy, 1985). In planning practice this is the technical knowledge that has reified human subjects and 'which makes a fetish of science' as the answer to society's ills (Habermas, 1996a: 63). Applied to planning practice, the theory of communicative action has led to the creation of participatory processes and spaces to allow this public sphere to flourish. The aim has been to create a shared intersubjective understanding between competing stakeholders (Healey, 1997) and examples of successful participatory processes work to create deep inclusion (for example: Quick \& Feldman, 2011; Sandercock, 2000), (Young, 2000).

A further use of the theory of communicative action has been as a yardstick to measure participation (Dryzek, 1995). It is the failure of participatory practices to reach the ideals of 
communicative action that has led to much of the criticism of communicative planning, as Hillier simply puts it: 'many planning strategies and/or disputes about development applications do not end in harmonious consensus.' (Hillier, 2003: 37). Indeed, from a Lacanian perspective 'conflict, antagonism and contradiction are not breakdowns of the system but rather lie at the heart of society and social change' (ibid.p.46). The emotionality, mess and tension of the real world mean that communicative practices are far from the ideal of rational communicative action (Barnes, 2008; Huxley, 2000).

Further, the tensions and conflict apparent in participatory practice, often reflecting underlying socio-economic inequalities, produce the sort of instrumental and strategic communication of the zweckrationalitet railed against by Habermas (Huxley, 2000; Huxley \& Yiftachel, 2000). The desire to reach consensus in communicative planning processes can mean deep underlying conflict is not surfaced or discussed (Brand \& Gaffikin, 2007) and 'the desirability for the legitimacy of a decision process may mean that a claim to consensus is made authoritatively irrespective of the level of agreement or of who might have been excluded from the process' (Bond, 2011: 171). In these cases it is agonism that resonates and explains participatory practices and so it is suggested 'planning theory needs to have conflict rather than 
consensus as its frame of reference' (McGuirk, 2001: 214). In terms of the evidence presented in the rest of this paper, it is important to recognise this critique of the possibilities of communicative action derives from in-depth analysis of individual moments of participation on specific issues or plans, rather than an understanding of communicative action as an ongoing process.

\section{Discourse}

In Habermas' critical theory, rational discourse embedded in the Lifeworld constitutes communicative action. It is through discourse that actors raise truth claims that are judged to form the basis of future action. The Foucauldian use of discourse as constitutive of society presents a very different idea of discourse to that used in the theory of communicative actions (Fischler, 2000; Flyvbjerg, 1998a) and also presents a critique to communicative planning.

Across a broad range of policy studies Foucault's methodology of genealogy (Foucault, [1980] 2003) and his theorisation of power/knowledge and governmentality (Foucault, [1978] 2003) have gained great traction as a critique of modernity (McKee, 2009). For those planners and policy analysts working with subalterns - groups who lack structural power and are being shaped by the governmentalities of the state (Cruikshank, 1999) - the searchlight of Foucauldian critique has been alluring. In 
research on urban regeneration (here defined as the range of policy initiatives aimed at supporting or "turning around" neighbourhoods characterised by concentrated deprivation (Cochrane, 2003: 234)) analysis of the genealogy of Foucauldian discourses has: highlighted and criticised the construction of the "problem" populations within policy documents (Atkinson, 2000; Hastings, 2000; Matthews, 2010; Watt \& Jacobs, 2000); problematised the very concept of regeneration itself (Furbey, 1999); and in relation to communicative planning practice, has revealed how partnerships to empower the community cannot live up to their idealistic objectives because of the inherent contradictions of the power/knowledge nexus (Atkinson, 1999; Collins, 1999; Cruikshank, 1999). As Fischler (2000) suggests it is the methodology of genealogy, and the questions it raises regarding what any consensus brought about by collaborative action might mean in terms of the exercise of power/knowledge that arguably offers the greatest critique to of the application of Habermas' theory in communicative planning.

Foucauldian interpretations have been criticised for finding every social relationship to be laden with power. This can lead social agency being downplayed or purposefully ignored for the sake of criticising something as "neo-liberal" (Barnett, 2005; Spicer \& Flemming, 2001). At its worst, these analyses make actors empty vessels waiting to be filled up with discourse 
(Spicer \& Flemming, 2001) and applied Foucauldian theory becomes 'Talcott Parsons updated' (Barnett, Clarke et al., 2008: 640). If this approach is unhelpful then we have to raise the question that was often posed to Foucault - where does critique lead us? (Foucault, [1980] 2003: 256). There is an inherent danger that analysis becomes "'critical criticism"" that will 'seduce us into despair and defeatism' (Bernstein, 1985: 8, 25) rather than pragmatic analysis that seeks to make policy better. The key issues debated in the literature on communicative planning is whether a public sphere can be created that allows the Lifeworld to sufficiently flourish to produce a discourse to counter power/knowledge (Fischler, 2000; Huxley, 2000).

\section{Power}

Communicative action in the Lifeworld is perceived by Habermas as an emancipatory force: "'Communicative reason operates in history as an avenging force", and the Lifeworld will always challenge the System if allowed to flourish (Habermas, 1982, cited in: Bernstein, 1985: 25). In collaborative planning this has been embraced to try and produce a radical democratisation of policy-making (Dryzek, 1995; Healey, 1997; Young, 2000). Through participatory techniques such as consensus conferences, citizens juries, partnerships and partnerships between street-level bureaucrats 
and citizens, policy-making is increasingly trying to bring the Lifeworld back into processes dominated by the System and zweckrationalitet (Barnes, Newman et al., 2007; Fischer, 2003; Wagenaar, 2007). As such, communicative planning becomes the operation of power in the sense of giving people the ability to effect change (Fischler, 2000).

Critiques of communicative planning present this belief in the emancipatory potential of communicative action as somewhat naïve. As we have seen above, one of these criticisms stems from a Foucauldian perspective of the intertwining of power and knowledge in discourse. As Flybjerg asserts: '[t]he value of Foucault's approach is his emphasis on the dynamics of power. Understanding how power works [in terms of technologies of governance and discourses] is the first prerequisite for action, because action is the exercise of power.' (Flyvbjerg, 1998a: 228). Planners are always doing and acting in a power-full way within a governmentality of planning systems. From an agonist perspective this ignores the underlying inequalities in power relations between the state and communities and that '[p]lanners operate within a 'hard infrastructure' of legal/administrative and institutional procedures, guidelines, and rules that are products of instrumental rationality' (McGuirk, 2001: 209). Within this frame '[1]iberal moral and/or legalistic projects, such as those of Habermas, are generally 
unrealizably utopian on anything but a small scale' (Hillier, 2003: 41).

Much of this critique derives from the analysis of moments of participation and evidence of the interaction between planners and communities (Beaumont \& Loopmans, 2008; Brand \& Gaffikin, 2007; McGuirk, 2001). The agonistic and unequal character of participation even applies to the cases presented below. However, by focusing on communicative action in spaces occupied by planners (or other policy-makers) and communities, this work ignores the public sphere of communicative action created by community groups. In the cases presented below this is a public sphere of working class, predominantly middle-aged, predominantly female, community activists committed to improving their neighbourhood for themselves and others (Grimshaw, 2011; Jupp, 2008).

To summarise this review of the debates around communicative planning, although Habermas is seen as 'morally admirable' (Flyvbjerg, 1998a: 229) his work, and responding critiques, have remained largely a theory of how planning ought to be carried out. The empirical evidence on which these broad discussions in planning theory are based predominantly focus on the process, and usual failure, of planners to create effective public spheres for the creation of communicative rationality. The rest of the paper presents evidence of communicative 
rationality by communities themselves, without the planners but responding to the decisions of planners.

\section{Planning the built environment, meaning and history}

The research sought to understand the meanings of one area of spatial planning policy - urban regeneration policy in Scotland between 1989 and 2009, and how meanings might have changed over this 20 year period (Yanow, 1996; Matthews, 2010; 2012). During the course of nine months of fieldwork in two case study neighbourhoods - Ferguslie Park in Renfrewshire, south of Glasgow and Wester Hailes in Edinburgh - overt non-participant observation (Gans, 1976) was used to collect data in meetings organised to engage the local community and community groups themselves (44 meetings in total). Narrative interviews (Hollway \& Jefferson, 2000) were also carried out with 27 community workers and local policy-makers and 16 community activists (43 in total). ${ }^{1}$ The unstructured narrative interview technique was specifically used to allow for the free association of ideas from peoples' experiences of living in the neighbourhoods and experiencing the built environment to their experiences of regeneration and planning processes and practices. Thus, although participants knew the subject of the research (the regeneration programmes)

\footnotetext{
${ }^{1}$ The broader research study was on the implementation of current policy. The evidence presented here focuses on the data from the 16 community activists.
} 
most of the evidence presented below was in answer to the opening question "can you tell me about your experiences of living in [name of place]?" The majority of the community activists had lived in the neighbourhoods most of their lives and had been involved in voluntary and state-led initiatives for over 40 years in some cases. For these participants the negotiated text of the narrative interview (Fontana \& Frey, 2000) became oral history, allowing them to recount their biographies and how their experiences of policy paralleled their lives (Diamond, 2005).

The interpretive ontology and epistemology underlying the research and analysis also accepted that the built environment of the neighbourhood told a story itself (Yanow, 1995). This recognised that through construction, existence, demolition and reconstruction, the built environment entered into a semiotic discourse with residents as they interpreted it and recognised what it symbolised and represented (Feldman, 1995). The methods used sought to capture the stories, metaphors, symbols and other tropes that implemented and created regeneration policy at the neighbourhood level (Shore \& Wright, 1997; Yanow, 1996; 2000). The methodology brought together these stories with evidence from ongoing community engagement around place - a process in Scotland called Community Planning (Cowell, 2004; Matthews, 2012) - which for community activists regularly relied on these stories to explain 
current problems and possible solutions. The history presented by these participants is subjective, but it was a live history being used and reconstructed in policy discussions (Matthews, 2012, in press).

The data gathered also included a broad record of official, semi-official, community and academic evidence, supported by easily accessible archives of newspaper cuttings covering the twenty years (Collins, 1999; Collins \& Gunson, 1997; Gilloran, 1983; Hastings, McArthur et al., 1994; Kintrea, 1996; McCrone, 1991; Paisley CDP, 1978a; 1978b). This enabled present policy and the activities of community activitists to be understood in their historical context - a perspective often ignored in policy analysis (Pollitt, 2008). The paper therefore presents the theoretical contribution of a much broader ethnographic ‘thick description' (Geertz, 1974; Yanow, 2000). The thickness of description is an essential part of providing a reliable and valid account to the reader (Schwartz-Shea \& Yanow 2009) and as such the theoretical contribution of this paper is supported by analysis published elsewhere (Anonymous, 2008; 2012a; 2012b).

Agonism and communicative rationality in Ferguslie Park and Wester Hailes

Ferguslie Park and Wester Hailes are two peripheral neighbourhoods dominated by socially rented housing. 
Ferguslie Park was predominantly low-rise tenement flats built in the 1930s that had been experiencing low demand since the mid-1960s (Paisley CDP, 1978a; 1978b). Wester Hailes was the last major local authority housing estate to be built in the UK with the majority of construction taking place from 1968 to 1971 and on construction was immediately an area of low demand housing (Gilloran, 1983). As with many peripheral social housing estates in the UK and Europe, by the mid-1980s both neighbourhoods were experiencing very low demand and vacancy problems following decades of state disinvestment, combined with problems of concentrated unemployment, worklessness and socio-economic deprivation (Dekker \& Van Kempen, 2004; Tunstall \& Coulter, 2006). In 1988, both neighbourhoods were chosen for the ambitious regeneration programme A New Life for Urban Scotland (Matthews, 2012; Scottish Office, 1988). Over a decade (1989-1999) the programme invested over $£ 400$ millions in four partnership neighbourhoods predominantly in capital expenditure on housing renewal (CPC, 1999).

The policy was widely criticised at the time and since (Johnstone \& McWilliams, 2005; Scottish Office, 1990; Turok, 2004). This body of criticism focused on two aspects of the policy. Firstly, the initial broad truth claim made about the cause of the urban "problem" and its solution; and secondly the deliberative environment the policy was meant to develop . As 
a product of a Conservative government the policy document defined the policy problem as working class communities in peripheral housing estates becoming dependent on the state (Hastings, 2000). Communities were to be made "responsible" through community ownership of their homes and the process of intense community engagement.

The process of developing partnerships was taking place when much of the emerging scholarship on communicative planning was emerging and the policy can be very much seen as part of the zeitgeist of modern urban governance in the late 1980s and early 1990s (Healey, Cameron et al., 1995). This community engagement through "partnership" was particularly problematic. It is well documented by the communities themselves (Hastings, McArthur et al., 1994, Collins, 1999), the policy evaluation (CPC, 1999), and academic research (Kintrea, 1996) that this attempt at community engagement was very much like the agonist processes described in much of the literature (Bond, 2011; Brand \& Gaffikin, 2007; McGuirk, 2001). It was widely recognised that community activists were not equal partners and the language of partnership was tokenistic (Hastings, McArthur et al., 1996; Kintrea, 1996; Nienhuis, Van Dijk et al., 2011). In Wester Hailes, community activists drafted a document called The Pitlochry Affirmation stating that "the community will do, not be done to" (quoted in: Hastings, McArthur et al., 1994). In Ferguslie Park the 
community partners were ejected from the partnership early on in the regeneration and the remaining years were spent rebuilding community representation (Kintrea, 1996; CPC, 1999). Collins' analysis of the discourses of partnership in Ferguslie Park, based on the work of Bakhtin (Collins and Gunson, 1997; Collins, 1999) underlines that the discourse genre of partnership used by the Scottish Office actually created conflict as it clashed with the discourse genre used by community activists fighting for improvements in their neighbourhoods. The result was the collapse of partnership working (Kintrea, 1996; Collins, 1999).

Returning to the neighbourhoods a decade after these regeneration partnerships meant this research could revisit the communities and understand how discourses had developed since the regeneration process ended - a story of where the neighbourhoods have been, what has happened to them, and what their future might be. This was not a given discourse of the Foucauldian sense, but a Habermasian deliberative discourse broad in subject and including the built environment as an agent. It was a discourse about planning and development but one that was not led by planners - they had left in 1999 when the regeneration of the neighbourhoods was "complete". The inverted commas around complete emphasise a double irony: questioning whether a process called regeneration can ever be complete and successful (Atkinson \& Moon, 1994; 
Shaw \& Porter, 2009); and highlighting that both

neighbourhoods still had concentrated deprivation and the associated problems, both being in the most deprived 15 per cent of neighbourhoods in Scotland.

\section{Discourse with the built environment}

Twenty years since the regeneration programmes in Wester Hailes and Ferguslie Park began the impact of the physical regeneration was still a ready topic of conversation. The stories that the narrative interview technique allowed to be told revealed two judgements on the redevelopment by community activists, a product of ongoing discourse after the initial planning decisions. The first of these is one of pleased acceptance - the new homes met a dire need for improved housing and gave tenants and residents something to be proud of. The second is more contingent, using the new homes and buildings to represent failed delivery and broken promises. The built environment was part of everyday life and was in discourse with community activists so '[w]e see here people jointly considering the extent to which certain maxims do and should hold for them, by taking their ordinary practices as objects of reflection.' (Barnett, Clarke et al., 2008: 646)

The discourse of community activists with their built environment began with the very poor quality housing that had existed before regeneration. In both neighbourhoods the 
problems with housing led to the emergence of community activism in the 1970s, increasingly supported by state-funded community development (Cockburn, 1977; Gilloran, 1983; Paisley CDP, 1978c; Taylor, 1988). The problems in the neighbourhoods differed. In Ferguslie Park they emerged as a combination of poor construction and maintenance, overcrowding and simultaneous low-demand and vacant properties being vandalised (Paisley CDP, 1978b; 1978a). One activist had moved to the neighbourhood from elsewhere in Paisley and was shocked by the poor quality of the housing. Their story of living in the neighbourhood included problems with mice in their dilapidated tenement, still heated from an open fire in the mid-1970s:

'especially when you've got young children it's quite frightening to find that you've got vermin running about your cooker an' things like that and them coming out of the fireplace to sit and watch TV wi' you it was quite scary at times. When we couldn't afford to have a fire lit when the fire was lit it was okay but when the fire wasn't lit the mice used to come out the grating an' just run aboot the place it was not nice at the time'

(Community activist)

The problems in the Wester Hailes were with modern, systembuilt high rise flats and also a general environment that had been designed with the car in mind: 'a bit short on the 
pavement department' as described by one community activist. Residents described the neighbourhood as being 'grey' and somewhere they would not have chosen to live. Many of the stories began with them becoming homeless and having to accept a house in the neighbourhoods.

The poor housing was recognised in the initial regeneration strategy documents published in 1989: 'Major investment is necessary to modernise Ferguslie Park's housing' (Ferguslie Park Partnership (FPP) 1989: 4); 'The strategic goals for housing in Wester Hailes are ... to improve physical standards.' (Wester Hailes Partnership (WHP), 1989: 8). New Life for Urban Scotland delivered this housing renewal through massive capital investment and as one research participant described 'it did exactly what it said on the tin’ (strategic officer). Over $£ 200$ millions were spent over ten years in the two neighbourhoods to refurbish housing and build new homes to replace those that were unfit (Matthews, 2012 in print). In Habermasian terms, the regeneration strategies raised a truth claim that the major problem in the neighbourhoods was poor housing. This was widely accepted by the communities: 'they [community activists] wanted the houses modernised or demolished an' new houses built at the end of the day. They wanted to get away from the tenemental properties' (community activist). The regeneration programme responded by investing in physical improvements. 
Understanding this truth claim from a historical perspective reveals how the final judgement on this policy was not based on truth claims raised at any one moment, or a single participation event. Indeed, it was conflicts about the high levels of subsidy offered to private developers and newly formed community-based housing associations that led to much of the conflict during the regeneration process especially in Ferguslie Park (Kintrea, 1996; Collins, 1999). Rather, the truth claim that new housing and physical regeneration would improve the neighbourhood ricocheted down time. The new and refurbished houses and new spaces were not "read" once on construction and completion and this interpretation then fixed. The discourse was ongoing with the readers, the community activists, changing their response to the text of the built environment as their lives changed. As they sought to find consensus on what regeneration had meant and what it could mean in the future, the built environment played different roles in this conversation.

In the stories recounted during interview, physical renewal was closely aligned to biographical details of personal and familial successes, such as a child moving into one of the new homes as a mortgaged purchaser rather than a tenant; or friends and relatives exercising the right-to-buy their socially-rented homes which was interpreted as a commitment to the neighbourhood. Activists who were fortunate to live in one of the newer 
housing association homes spoke of their friends in local authority homes being ashamed of their neighbourhood and home.

This positive story had particular resonance in community activists' stories because of the intense feeling of injustice linked to stigma (for a discussion on the nature of stigma towards social housing estates in the UK see: Hastings, 2004). Both the neighbourhoods had gained notoriety and stigma predominantly because of the poor built environment and historic housing allocation decisions. In Ferguslie Park the regeneration strategy explicitly sought to improve the 'exaggeratedly bad image' of the neighbourhood (FPP, 1989). Community activists linked the impact of the stigma of their address to their everyday lives. This was commonly explained as being let down by local service providers, or that more affluent neighbourhoods received better service quality:

'I mean because you've got likes of [neighbouring more affluent area] and places like that where they do on the whole get a lot more done for them ... I used to see it quite a lot you know where they were getting pickups in rubbish bins and things like that put into them you know a lot more then what we did'

(Community activist) 
There was also a feeling both neighbourhoods had been used as a 'dumping ground' for difficult tenants, without the necessary support to maintain tenancies, the wider neighbourhood or communities. Among resident activists the expected norm derived from this injustice was that any policy action should be a sufficiently large investment to overcome historic problems; as one community activist described it: 'there has to be more. What? I don't know. But there has to be more'. As such, the capital investment in the built environment was interpreted as the one sufficiently large investment that had occurred to meet the needs of the neighbourhood.

The communicative rationality among the residents allowed for this positive interpretation. However, through their discourse they also explored the shades of grey around what regeneration meant. Subsequently another common interpretation was that the regeneration had offered nothing except physical renewal, recognising the continued problems of concentrated deprivation. As one community activist commented:

'to me the whole of the partnership the only real thing that I seen that's been achieved is the change in the housing and I don't know if that's just me personally but that's all I see in in twenty years I've lived here is housing.'

(Community activist) 
One key example of this is the interpretation and symbolic use of the Tannahill Community Centre in Ferguslie Park. This modern building, opened by Queen Elizabeth in 1995, was emblematic of the wider failure of regeneration. The community had struggled to make full use of the space and as it had remained under the management of the local authority, community activists had never felt fully empowered to own the space; as one activist described, they were working on:

'changing this into what can be a community centre to benefit this community because this buildin' doesn't. It's whi- it's painted the right colour it's a white elephant.'

(Community activist)

In this activist's story the white elephant of the Tannahill Centre spoke to the problems of Ferguslie Park and the concentrated deprivation and everyday problems that still continued and that there was a need for "more" in the neighbourhood. In a dialogue with the built environment, the Centre represented the promises of empowerment offered to the community - of a community-run centre to benefit the community - that had been broken as the regeneration process became dominated by government partners.

As mentioned above, community engagement in the regeneration partnerships was difficult and fraught with 
tension. The discourse described above also allowed this to be reinterpreted as the consensus on the process of regeneration was debated. A unique aspect of the New Life regeneration partnerships was that as an expression of commitment, the UK Government Scottish Office appointed a senior civil servant to the chair of each partnership boards (Scottish Office, 1988). This meant the community activists most heavily involved in the partnerships and who sat on the board, felt a great sense of respect for some of these figureheads. Charged with implementing a policy in partnership with the community, these chairs worked hard to help communities and had a key role as a broker in delivering the policy. This was not always seen positively by senior officials at Scottish Office headquarters. As explained by one community activist:

"the initial lead officer we had from the Scottish Office ... was moved because he was seen to be too familiar with the local local authority mainly, but also with the local community. He tended to be quite open about what they were trying to achieve in the area ... it didn't always have to be done in a formal way if you know what I mean? It became quite informal at the end"

(Community activist)

One interpretation of similar relationships has been that it represents the co-option of activists into the power/knowledge nexus of the regeneration partnership (Atkinson, 1999). In these 
activists' stories of regeneration, the relationship was characterised as one of trust and respect. Another community activist described how their chairperson was readily available to be spoken to: 'I would be allowed to phone [the chairperson] ... or phone [name] his secretary'. When the chairs were moved-on because they had become "too familiar" this bond of trust and respect was broken, with a matched break down of relationships between partners.

This discourse among residents and between residents and their built environment, about the planning and regeneration of these neighbourhoods was allowing the initial truth claims of the regeneration to be constantly tested and used to understand how the neighbourhood was continuing to evolve. This discourse was constitutive of the world of these community activists, but it was evolving and questionning. Unlike in the tense moments of participation in the 1990s, the discourse was flourishing in the Lifeworld of a public sphere of middle-aged, predominantly female, community activists. This Lifeworld also had critical power (Bernstein, 1985). Communicative action enabled these activists to reinterpret the improvements to the built environment as a positive and negative change, and to understand the process that they had gone through over ten years of dramatic upheavals and political tensions. As 'little Habermasians' the grey areas in between intersubjective 
understanding were still open for exploration as the regeneration settled and the policy world continued to move on.

\section{Policy action and the Lifeworld}

For these long term resident activists, regeneration was not a single ten-year planning event. It was an everyday process of coping with the complex problems produced by the spatial concentration of individual problems in their neighbourhood (Atkinson \& Kintrea, 2004; Wagenaar, 2007). Inter-subjective understanding as to what regeneration might mean could not be achieved in the fraught atmosphere of a rapid regeneration process. The discourse with the built environment over 20 years of change and mixed improvement described above allowed for this and provided a context for an ongoing negotiation of what regeneration might mean. For example, discussing and comparing local environmental problems and what may be done to tackle these (Hastings, 2007), or discussing the youth anti-social behaviour that had occurred over the weekend and whether the Police had been contacted. These processes of everyday regeneration took place in domestic or informal settings (Jupp, 2008). These ranged from the shared story or joke across the table at a tenants' and residents' association meeting, to a quick catch-up when walking about the neighbourhood. The communicative action of these people in meetings was active debate about 'the gray areas in between' of 
the truth of local deprivation and what regeneration had been and could be. The activists were 'little Habermasians' (Barnett, Clarke, Cloke \& Malpass, 2008: 646) making truth claims about their experiences and what policy intervention might make their lives better.

A common occurrence of this was debates about youth antisocial behaviour and what should be done to stop it.

Discussions often began with the characterisation of the perpetrators as young tearaways who needed boot-camp treatment. This would be tempered by the personal experience of others who had been volunteers with youth groups or had problems with their own young relatives. This redefined the problem as one of a lack of opportunity, for things to do in the evening and also in the longer term for employment and education. A more holistic solution to the problem then made sense within the negotiated truth and rightness of youth antisocial behaviour as understood through communicative action.

These deliberative environments were a public sphere allowing the Lifeworld of these resident activists to flourish, uncorrupted by the technicism of the System, empowering them to understand their experiences of regeneration in their own terms (Dargan, 2007; Habermas, 1996a; Jupp, 2008). Community activist narratives would often include dismissive comments about the bad choices of planners in the past creating the poor 
neighbourhoods they lived in. They would readily and knowingly use the historic euphemisms of planners to describe the problems of their neighbourhood - 'under-privileged', 'a deprived area' - and link this to their narrative of successive policies (Diamond, 2005). The residents thus had an institutional memory (Pollitt, 2008) of these various initiatives, usually greater than that of the professionals with whom they engaged, and debated the rights and wrongs of each approach.

\section{Conclusion}

In the analysis of community activity in Wester Hailes and Ferguslie Park, Habermas' critical theory could not be used as a normative "ought" to which policy should aspire as in communicative planning (Healey, 1997; Flyvbjerg, 1998a) nor as a yardstick to measure participatory practices (Dryzek, 1995). Rather Habermas' theory emerged abductively as an explanation of the "is" - of the everyday deliberative practices of community activists. The historical approach taken questions the assumption that the depth of intersubjectivity required of communicative action can never be achieved. The historicity of the analysis suggests it is naïve to assume intersubjective understanding can be reached in a rapidly moving planning and policy-making process (McGuirk, Brand and Gaffikin 2001). What was most important for the community activists in Wester Hailes and Ferguslie Park was to be given the time to 
understand what the changes in the built environment meant to them and use them in their everyday practical discourses.

The discourse with and about the built environment in Wester Hailes and Ferguslie Park had developed over two decades since the beginning of the regeneration process. Over this time, communicative action has created an intersubjective understanding with the built environment. This discourse in the Lifeworld also produced some of the emancipatory potential theorised by Habermas. The discourse enabled communities to challenge definitions of "deprivation" and "regeneration" placed upon them and to understand the regeneration process in their own terms, both positive and negative (Matthews, 2012 in print). These discourses were enmeshed in much larger biographies and were then developed through practices of discourse in the public sphere of community meetings and exchanges on the street.

Using Habermas' critical theory in this way, this paper builds on the growing body of pragmatic thought and application of pragmatism in planning and policy analysis (Flyvbjerg, 2001; Healey, 2009). The discourse of the community activists, over time, in these neighbourhoods demonstrates communicative action producing a pragmatic judgement and outcome. The understanding that had settled at the time of the fieldwork was that the physical regeneration and particularly the 
improvements to the housing conditions were the right, practical thing to do at the time. This resonates with the findings from regeneration experiences, where physical renewal made residents feel more secure and happier in their neighbourhood (Manzi \& Jacobs, 2009) and that community activists will prioritise physical renewal and capital investment for the rapid improvements it delivers even if this is not the most "rational" policy action (Lawless, 2004; 2006).

In terms of practices of communicative planning it also adds to our understanding of processes of institutional capacity building (Innes \& Booher, 2003). Examples of successful collaborative approaches to policy-making often focus on the long-term nature of processes of building governance capacity, institutional capacity and trust (Innes \& Booher, 2003; Barry, 2012). The evidence presented here suggests that we also need to consider the built environment itself as part of those institutions. Buildings may not be of sufficient quality to warrant specific legislative protection, but the evidence from Wester Hailes and Ferguslie Park is that changes to the built environment continue to help communities to understand their lived experience and constantly recreate new meanings and new solutions to challenges. Any future redevelopment processes and associated collaborative forums need to recognise this if they are to achieve a level of intersubjective understanding with residents, and further should harness this 
knowledge and the intersubjective understandings of residents, to inform future visions. References

Ashenden, S. and D. Owen (1999). Introduction: Foucault, Habermas and the politics of critique. Foucualt Contra Habermas. Ashenden, S. and Owen, D. London, Sage: 1-20.

Atkinson, R. (1999). "Discourses of partnership and empowerment in contemporary British urban regeneration." Urban Studies 36(1): 5972.

Atkinson, R. (2000). "Narratives of policy: the construction of urban problems and urban policy in the official discourse of British government 1968-1998." Critical Social Policy 20(2): 211-232.

Atkinson, R. and K. Kintrea (2004). "'Opportunities and despair, it's all in there': practitioner experiences and explanations of area effects and life chances." Sociology 38(3): 437-455.

Atkinson, R. and G. Moon (1994). Urban Policy in Britain: The City, the State and the Market. Basingstoke, Macmillan.

Barnes, M. (2008). "Passionate participation: emotional experiences and expressions in deliberative forums." Critical Social Policy 28(4): $461-481$.

Barnes, M., J. Newman, et al. (2007). Power, Participtation and Political Renewal: Case Studies in Public Participation. Bristol, Policy Press. 
Barnett, C. (2005). "The consolations of 'neoliberalism'." Geoforum 36: $7-12$.

Barnett, C., N. Clarke, et al. (2008). "The elusive subjects of NeoLiberalism." Cultural Studies 22(5): 624-653.

Barry, J. (2012). "Indigenous State Planning as Inter-

Institutional Capacity Development: The Evolution of

Government-to-Government Relations in Coastal British

Columbia, Canada." Planning Theory and Practice 13(2): 213 231.

Beaumont, J. and M. Loopmans (2008). "Towards Radicalized

Communicative Rationality: Resident Involvement and Urban

Democracy in Rotterdam and Antwerp." International Journal of

Urban and Regional Research 32(1): 95-113.

Bernstein, R. (1985). Introduction. Habermas and Modernity.

Bernstein, R. Cambridge, Polity Press: 1-32.

Bernstein, R. J. (1983). Beyond Objectivism and Relativism:

Science, Hermeneutics and Praxis. Oxford, Basil Blackwell.

Bond, S. (2011). "Negotiating a "democratic ethos"." Planning

Theory 10(2): 161-186.

Brand, R. and F. Gaffikin (2007). "Collaborative Planning in an Uncollaborative World." Planning Theory 6(3): 282-313.

Cochrane, A. (2003). The new urban policy: towards empowerment or incorporation? The practice of urban policy. Urban Renaissance? 
New Labour, Community and Urban Policy. Imrie, R. and Raco, M.

Bristol, Polity Press: 223-234.

Cockburn, C. (1977). The Local State: Management of Cities and

People. London, Pluto Press.

Collins, C. (1999). "Applying Bakhtin in urban studies: the failure of community participation in the Ferguslie Park Partnership." Urban Studies 36(1): 73-90.

Collins, C. and D. Gunson (1997). "From the I to the we: discourse, ethics, identity, and the pragmatics of partnership in the west of Scotland." Communication Theory 7(4): 278-300.

Cook, D. (2005). "The sundered totality of system and lifeworld." Historical Materialism 13(4): 55-78.

CPC (1999). An Evaluation of the New Life for Urban Scotland Initiative in Castlemilk, Ferguslie Park, Wester Hailes and Whitfield Edinburgh, Scottish Executive.

Cruikshank, B. (1999). The Will to Empower: Democratic Citizens and Other Subjects. London, Cornell University Press.

Dargan, L. (2007). "Conceptualising regeneration in the New Deal for Communities." Planning Theory \& Practice 8(3): 345-362.

Dekker, K. and R. Van Kempen (2004). "Large housing estates in Europe: current situation and developments." Tijdschrift voor Economische en Sociale Geografie 95(5): 570-577. 
Diamond, J. (2005). "Reflecting on the processes of a local evaluation: networks, narratives and partnerships." International Journal of Public Sector Management 18(2): 178-189.

Dryzek, J. (1995). Critical theory as a research program. The Cambridge Companion to Habermas. White, S. Cambridge, Cambridge University Press: 97-119.

Feldman, M. S. (1995). Strategies for Interpreting Qualitative Data. London, Sage.

Finlayson, J. G. (2005). Habermas: A Very Short Introduction. Oxford, Oxford University Press.

Fischer, F. (2003). Reframing Public Policy: Discursive Politics and Deliberative Practices. Oxford, Oxford University Press.

Fischer, F. and J. Forester (1993). Editor's Introduction. The Argumentative Turn in Policy Analysis and Planning. Fischer, F. and Forester, J. London, UCL Press: 1-20.

Fischler, R. (2000). "Communicative Planning Theory: A Foucauldian Assessment." Journal of Planning Education and Research 19(4): 358-368.

Flyvbjerg, B. (1998a). "Habermas and Foucault: thinkers for civil society." British Journal of Sociology 49(2): 210-233.

Flyvbjerg, B. (1998b). Rationality and Power: Democracy in Practice. London, University of Chicago Press. 
Flyvbjerg, B. (2001). Making Social Science Matter: Why Social Inquiry Fails and How It Can Succeed Again. Cambridge, Cambridge University Press.

Fontana, A. and J. Frey (2000). The interview: from structured questions to negotiated text. Handbook of Qualitative Research. Denzin, N. and Lincoln, Y. London, Sage: 645-672.

Forester, J. (1993). Critical Theory, Public Policy, and Planning Practice: Towards a Critical Pragmatism. New York, State University of New York Press.

Foucault, M. (2003). What is enlightenment. The Essential Foucault. Rabinow, P. and Rose, N. London, The New Press: 43-57.

Foucault, M. ([1978] 2003). Governmentality. The Essential Foucault. Rabinow, P. and Rose, N. London, The New Press: 229245.

Foucault, M. ([1980] 2003). Questions of Method. The Essential Foucault. Rabinow, P. and Rose, N. London, The New Press: 246258.

FPP (1989). A Pattern For New Life: Strategy for the Regeneration of Ferguslie Park. Edinburgh, Scottish Office.

Furbey, R. A. (1999). "Urban 'regeneration': reflections on a metaphor." Critical Social Policy 19(4): 419-445.

Gans, H. (1976). On the methods used in this study. The Research Experience. Golden, M. P. Itasca, IL., F.E. Peacock: 49-59. 
Geertz, C. (1974). ""From the native's point of view": On the nature of anthropological understanding." Bulletin of the American Academy of Arts and Sciences 28(1): 26-45.

Gilloran, A. (1983). Wester Hailes Ten Years On. Edinburgh, Wester Hailes Representative Council.

Grimshaw, L. (2011). "Community work as women's work? The gendering of English neighbourhood partnerships." Community Development Journal 46(3): 327-340.

Habermas, J. (1985). Questions and counterquestions. Habermas and Modernity. Bernstein, R. Cambridge, Polity Press: 192-216.

Habermas, J. (1989). The Structural Transformation of the Public Sphere: An Inquiry Into a Category of Bourgeois Society. Oxford, Polity Press.

Habermas, J. (1996a). Technology and science as "ideology". The Habermas Reader. Outhwaite, W. Cambridge, Polity Press: 53-65. Habermas, J. (1996b). What is universal pragmatics? The Habermas Reader. Outhwaite, W. Cambridge, Polity Press: 118-131.

Hastings, A. (2000). "Connecting lnguistic structures and social practices: a discursive approach to social policy analysis." Journal of Social Policy 27(2): 191-211.

Hastings, A. (2004). "Stigma and social housing estates: beyond pathological explanations." Journal of Housing and the Built Environment 19(3): 233-254. 
Hastings, A. (2007). "Territorial justice and neighbourhood environmental services: a comparison of provision to deprived and better-off neighbourhoods in the UK." Environment and Planning C: Government and Policy 35(6): 896-917.

Hastings, A., A. McArthur, et al. (1994). Community Participation and Partnership in Estate Regeneration Projects: Case Study Report No.2: The Wester Hailes Partnership. Glasgow, University of Glasgow, Training and Employment Research Unit.

Hastings, A., A. McArthur, et al. (1996). Less Than Equal?

Community Organisations and Estate Regeneration Partnerships.

Bristol, The Policy Press.

Healey, P. (1997). Collaborative Planning: Shaping Places in

Fragmented Societies. Basingstoke, Macmillan.

Healey, P. (2003). "Collaborative Planning in Perspective." Planning Theory 2(2): 101-123.

Healey, P. (2009). "The pragmatic tradition in planning thought." Journal of Planning Education and Research 28: 277-292.

Healey, P., S. Cameron, et al. (1995). Introduction: the city crisis change and invention. Managing Cities: The New Urban Context. Healey, P., Cameron, S., Davoudi, S., Graham, S. and Madani-Pour, A. Chichester, John Wiley: 1-20.

Hillier, J. (2003). "'Agon'izing Over Consensus: Why Habermasian Ideals cannot be 'Real'." Planning Theory 2(1): 37-59. 
Hollway, W. and T. Jefferson (2000). Doing Qualitative Research

Differently: Free Association, Narrative and the Interview Method.

London, Sage.

Huxley, M. (2000). "The Limits to Communicative Planning."

Journal of Planning Education and Research 19(4): 369-377.

Huxley, M. and O. Yiftachel (2000). "New Paradigm or Old Myopia? Unsettling the Communicative Turn in Planning Theory." Journal of Planning Education and Research 19(4): 333-342.

Innes, J. E. and D. E. Booher (2003). Collaborative policymaking: governance through dialogue. Deliberative Policy Analysis: Understanding Governance in the Network

Society. Hajer, M. A. and Wagenaar, H. Cambridge, Cambridge University Press: 33-59.

Johnstone, C. and C. McWilliams (2005). Urban policy and the city in the 'new' Scotland. Exploring Social Policy in the 'New' Scotland. Mooney, G. and Scott, G. Bristol, Polity Press: 157-176.

Jupp, E. (2008). "The feeling of participation: everyday spaces and urban change." Geoforum 39: 331-343.

Kintrea, K. (1996). "Whose partnership? Community interests in the regeneration of a Scottish housing scheme." Housing Studies 11(2): 287-306. 
Lawless, P. (2004). "Locating and explaining area-based urban initiatives: New Deal for Communities in England." Environment and Planning C: Government and Policy 22(3): 383-399.

Lawless, P. (2006). "Area-based urban interventions: rationale and outcomes: the New Deal for Communities programme in England." Urban Studies 43(11): 1991-2011.

Manzi, T. and K. Jacobs (2009). From a 'society of fear' to a 'society of respect': the transformation of Hackney's Holly Street estate. $\underline{\text { Regenerating London: Governance, Sustainability and Community in }}$ a Global City. Imrie, R., Lees, L. and Raco, M. London, Routledge: $273-288$

Matthews, P. (2010). "Mind the Gap?: The persistence of pathological discourses in urban regeneration policy." Housing Theory and Society 27(3): 221-240.

Matthews, P. (2012). "From area-based initiatives to strategic partnerships: have we lost the meaning of regeneration?" Environment and Planning C: Government and Policy 30(1): $147-$ 161.

Matthews, P. (forthcoming). "Re-interpreting and re-evaluating policy: the real successes of a regeneration policy." Critical Policy $\underline{\text { Studies }}$

May, T. and B. Perry (2011). Social Research and Reflexivity: Content, Consequence and Context. London, Sage. 
McCarthy, T. (1985). Reflections on rationalization in the Theory of Communicative Action. Habermas and Modernity. Bernstein, R.

Cambridge, Polity Press: 177-191.

McCrone, G. (1991). "Urban renewal: the Scottish experience."

Urban Studies 28(6): 919-938.

McGuirk, P. M. (2001). "Situating communicative planning theory: context, power, and knowledge." Environment and Planning A 33(2): $195-217$

McKee, K. (2009). "Post-Foucauldian governmentality: what does it offer critical social policy analysis?" Critical Social Policy 29(3): 465-486.

Nienhuis, I., T. Van Dijk, et al. (2011). "Let's collaborate! But who's really collaborating? Individual Interests as a Leitmotiv for Urban Renewal and Regeneration Strategies." Planning Theory \& Practice 12(1): 95-109.

Outhwaite, W. (1996). General Introduction. The Habermas Reader.

Outhwaite, W. Cambridge, Polity Press: 1-22.

Paisley CDP (1978a). Housing Allocation and Social Segregation. Paisley, Paisley CDP.

Paisley CDP (1978b). A Profile of Ferguslie Park. Paisley, Paisley CDP.

Paisley CDP (1978c). Westmarch Action Group: A Fight for Improvements. Paisley, Paisley CDP. 
Pollitt, C. (2008). Time, Policy, Management: Governing With the Past. Oxford, Oxford University Press.

Quick, K. S. and M. S. Feldman (2011). "Distinguishing participation and inclusion." Journal of Planning Education and Research 31(3): $272-290$

Rhodes, R. A. W. (1997). Understanding Governance: Policy

Networks, Governance, Reflexivity and Accountability.

Buckingham, Open University Press.

Sandercock, L. (2000). "When Strangers Become Neighbours:

Managing Cities of Difference." Planning Theory \& Practice 1(1): 13-30.

Scottish Office (1988). New Life For Urban Scotland. Edinburgh, Scottish Office.

Scottish Office (1990). Urban Scotland into the 90s: Report of the

Conference held in the Forum Hotel, Glasgow, from the 14th - 16th

May 1990. Edinburgh, Scottish Office.

Schwartz-Shea, P. and D. Yanow (2009). Reading and writing as method: In search of trustworthy texts. Organizational Ethnography: Studying the Complexities of Everyday Life. Ybema, S., Yanow, D., Wels, H. and Kamsteeg. London, Sage: $56-82$. 
Shaw, K. and L. Porter (2009). Introduction. Whose Urban

Renaissance? An International Comparison of Urban Regeneration

Strategies. Shaw, K. and Porter, L. London, Routledge: 1-7.

Shore, C. and S. Wright (1997). Policy: a new field of anthropology.

Anthropology of Policy: Critical Perspectives on Governance and

Power. Shore, C. and Wright, S. London, Routledge: 3-39.

Spicer, A. and P. Flemming (2001). Making Constructivism Critical:

$\underline{\text { Structure, Text and Contestation. Critical Management Studies }}$

Conference, UMIST, Manchester.

Taylor, P. (1988). "The urban programme in Scotland." Local

Economy 3(3): 205-218.

Tunstall, R. and A. Coulter (2006). Twenty-Five Years on Twenty

Estates: Turning the Tide? York, Joseph Rowntree Foundation.

Turok, I. (2004). Scottish urban policy: continuity, change and uncertainty post-devolution. New Horizons in British Urban Policy: Perspectives on New Labour's Urban Renaissance. Johnstone, C. and Whitehead, M. Aldershot, Ashgate: 111-128.

Wagenaar, H. (2007). "Governance, complexity, and democratic participation: how citizens and public officials harness the complexities of neighbourhood decline." The American Review of Public Administration 37(1): 17-50.

Watt, P. and K. Jacobs (2000). "Discourses of social exclusion: an analysis of Bringing Britain Together: a National Strategy for 
Neighbourhood Renewal." Housing, Theory and Society 14(1): 17-

26.

White, S. (1995). Reason, modernity and democracy. The Cambridge

Companion to Habermas. White, S. Cambridge, Cambridge

University Press: 3-16.

WHP (1989). Realising the Potential: The Partnership Strategy for

Wester Hailes. Edinburgh, Scottish Office.

Yanow, D. (1995). "Built space as story: the policy stories that buildings tell." Policy Studies Journal 23(3): 407-422.

Yanow, D. (1996). How Does a Policy Mean?: Interpreting Policy

and Organizational Actions. Washington D.C., Georgetown

University Press.

Yanow, D. (2000). Conducting Interpretive Policy Analysis. London, Sage.

Young, I. M. (2000). Inclusion and Democracy. Oxford, Oxford

University Press. 